\title{
The Tolerability and Safety of Repeated Sputum Induction in Patients with Moderate to Severe Chronic Obstructive Pulmonary Disease
}

\author{
Sanja Popović-Grle ${ }^{1}$, Zoran Manojlović ${ }^{2}$, Paško Konjevoda ${ }^{3}$, Latica Friedrich ${ }^{4 *}$ \\ and Katarina Orešković ${ }^{5}$ \\ ${ }^{I}$ University Hospital Centre Zagreb, Clinical Department for Lung Diseases Jordanovac, Medical School \\ University of Zagreb, Jordanovac 104, 10000 Zagreb, Croatia. \\ ${ }^{2}$ Croatian Institute for Toxicology and Antidoping, Borongajska cesta 83 G, 1000 Zagreb, Hrvatska. \\ ${ }^{3}$ Ruđer Bošković Institute, Bijenička c. 54, 10000 Zagreb, Croatia. \\ ${ }^{4}$ Medical School University of Zagreb, Zagreb, Croatia, Clinical Hospital "Sveti duh", Sveti duh 64, 10000 \\ Zagreb. \\ ${ }^{5}$ Triadelta Partners Ltd, Međimurska 19, 10090 Zagreb, Croatia.
}

\begin{abstract}
:
Background: Sputum induction is a method used over the years to investigate airway inflammation in patients with asthma and chronic obstructive pulmonary disease (COPD), to establish correct disease phenotype. Sputum production and expectoration are induced by inhaling hypertonic saline, which can also provoke adverse effects such as bronchoconstriction, lung hyperinflation, and dyspnea. The aim of this retrospective study was to assess the tolerability and safety of sputum induction in patients with more severe COPD stages. Methods: A total of 76 sputum inductions were performed in 20 patients with moderate or severe COPD (median FEV 1.6 L [95\%CI 1.47-1.71], or 51\% [95\% CI 47-54\%] of predicted) over a period of 32 days. Unique advantage of this study is multiple sputum induction in same patient. After premedication with $200 \mu \mathrm{g}$ salbutamol, subjects inhaled increasing concentrations of aerosolized saline $(0.9 \%, 3 \%$, $4 \%$ and $5 \%)$, each for 7 minutes. FEV $V_{1}$ was recorded prior to induction and after each inhalation interval. Results: The median fall of FEV $V_{1}$ at the end of sputum induction was $127 \mathrm{~mL}(95 \%$ CI 90-176 $\mathrm{mL}$ ) or 10\% (95\% CI 7-11\%) from baseline post-bronchodilator value. In 11 cases (14\%) the procedure was terminated due to an excessive bronchoconstriction (fall in FEV $>20 \%$ from baseline). None of the subjects reported adverse events. Conclusions: Sputum induction is safe and well tolerated by patients with moderate to severe COPD, which supports its use in clinical and research practice. Patients with a more severe airway obstruction may have a higher risk of excessive bronchoconstriction, precaution measures should be anticipated in those patients.
\end{abstract}

Keywords: Lung function, clinical trial

\section{Introduction}

Sputum induction is a method for obtaining sputum by inhalation of hypertonic saline, used frequently for investigation of airway inflammation in patients with chronic obstructive pulmonary disease (COPD) or asthma. Modern respiratory science is aware of different phenotypes in COPD $(1,2)$ and asthma (3), and new entities like asthma-COPD overlap syndrome (ACOS) (4). This diversity of phenotypes triggers the need for appropriate diagnostics and personalized treatment. The method of sputum induction with hypertonic saline was firstly introduced in asthma patients by Pin et al. in 1992 (5), and has been evolving ever since. As a relatively non-invasive procedure, which provides repeatable and valid results (6), sputum induction quickly gained an important place in clinical practice. Inhaled hypertonic saline, however, can cause adverse effects such as bronchial constriction and lung hyperinflation (7), and the safety of the method was thoroughly assessed in patients with airway obstruction characteristic for asthma $(8,9,10,11)$ and $\operatorname{COPD}(12,13,14,5,16)$. Despite a number of studies, there are limited data on the safety of sputum induction in COPD patients with pronounced airway obstruction, making physicians hesitant to use this valuable diagnostic tool in such patients. Our objective was, therefore, to assess the tolerability and safety of sputum induction in patients with moderate to severe COPD by measuring the changes in forced expiratory volume in one second $\left(\mathrm{FEV}_{1}\right)$ during the induction and by evaluating the occurrence of adverse events. 


\subsection{Study design}

\section{Patients And Methods}

Data pertaining to the sputum induction procedure, obtained during a randomised, double blind, placebo-controlled, parallel group study of the influence of azithromycin on inflammation markers in COPD patients, were analysed retrospectively. Details of the study design are provided elsewhere (18). Briefly, eligible patients with moderate to severe COPD were randomised in a 2:1 ratio to receive azithromycin (500 mg daily over 3 days, $n=16)$ or placebo $(n=8)$ once daily for 3 days in a randomized, double blind fashion. Sputum induction and other study assessments were done prior to the first dose (Day 1) and on Days 4, 11 and 32 . The same person underwent the sputum induction process at four occasions. The study was conducted according to the principles of good clinical practice and current version of the Declaration of Helsinki and was approved by ethics committee and regulatory authorities. A written informed consent was obtained from each patient prior to their participation in the study. Results on inflammatory parameters have been published elsewhere (18).

\subsection{Human subjects}

A total of 24 male COPD patients aged between 47 and 71 years, with moderate to severe COPD according to the Global Initiative for Chronic Obstructive Lung Disease (GOLD) standards (19), a negative salbutamol test ( $<12 \% \mathrm{FEV}_{1}$ improvement after salbutamol inhalation), and no clinically significant chest X-ray abnormalities, were included in the study. The median $\mathrm{FEV}_{1}$ value in the study population was $1.6 \mathrm{~L}(95 \%$ confidence interval [CI] $1.47-1.71 \mathrm{~L})$, or $51 \%$ of predicted $(95 \% \mathrm{CI} 47-54 \%)$. All subjects had a $\mathrm{FEV}_{1} / \mathrm{FVC}$ ratio under 0.70 .

During the whole study period, patients were not to receive immunosuppressive drugs, analgesic/antiinflammatory drugs (except paracetamol), long-acting beta-agonists, theophylline, acetylcysteine, antimicrobials, vitamins/antioxidants or phyto-pharmaceutical substances.

\subsection{Spirometry and salbutamol test}

Spirometry was performed at screening (within 7 days prior to Day 1) and before each sputum induction. On each occasion spirometry was repeated at least three times until two reproducible efforts were obtained. The two largest forced vital capacity $(\mathrm{FVC})$ and $\mathrm{FEV}_{1}$ values had to show less than $5 \%$ variability. Screening spirometry was followed by inhalation of $400 \mu \mathrm{g}$ of salbutamol, administered by a metered dose inhaler, to check for salbutamol reversibility. After 30 minutes, spirometry was repeated three times and the highest $\mathrm{FEV}_{1}$ value was recorded and used to assess the reversibility of bronchoconstriction. Regularly used bronchodilators were withheld for $8 \mathrm{~h}$ before starting the salbutamol test.

\subsection{Sputum induction}

Sputum induction was performed on study Day 1 (within 2 hours prior to the first dose), 4, 11 and 32. Each sputum induction was preceded by spirometry and patients with $\mathrm{FEV}_{1}<35 \%$ of predicted were excluded from induction procedure. The others had premedication with $200 \mu \mathrm{g}$ salbutamol and 10 minutes later $\mathrm{FEV}_{1} \mathrm{was}$ measured three times. The highest $\mathrm{FEV}_{1}$ value obtained was considered as baseline and was used to calculate a relative fall in $\mathrm{FEV}_{1}$ during the procedure. Sputum induction was performed by inhalation of increasing concentrations of aerosolized saline $(0.9 \%, 3 \%, 4 \%$ and $5 \%)$ through a mouthpiece without a nose clip. The aerosol was generated with an OMRON NE U07 ultrasonic nebulizer (Omron Healthcare Europe) with an output of $1.0 \mathrm{~mL} / \mathrm{min}$ and particle size of $3.5 \mu \mathrm{m}$ mass median diameter. Each concentration was inhaled over 7 minutes. After each inhalation, the patient was asked to expectorate into a container and $\mathrm{FEV}_{1}$ was measured again. If there was a fall in $\mathrm{FEV}_{1}$ of $10-20 \%$ versus baseline, the same concentration of saline was used in the next inhalation interval. If the fall was greater than $20 \%$, the procedure was terminated and the patient received a standardized treatment (nebulized $1 \mathrm{~mL}$ of salbutamol solution with $2 \mathrm{~mL}$ of normal saline). Patients were instructed to interrupt the inhalation if they need to expectorate (in this case the clock was stopped and inhalation continued after expectoration) or experience dyspnoea or wheezing. All adverse events occurring during the study, including those associated with sputum induction, had to be recorded.

\subsection{Statistical analysis}

In order to assess the potential treatment effect on response to sputum induction, the relative fall of $\mathrm{FEV}_{1}$ was compared between the active treatment group and the placebo group for each day and each inhalation interval using the Mann-Whitney U test. As there were no significant differences between active treatment and placebo group (Mann-Whitney U, for all groups $\mathrm{p}>0.05$ ), further analyses were made considering all subjects as a single group. Friedman's ANOVA was used for comparing FEV 1 changes between the days. Statistical significance was set at $\mathrm{p}<0.05$. All data were analysed using STATISTICA, version 8.0 (StatSoft, Inc. 2008). 


\section{Results}

A total of 76 sputum inductions were performed in 20 patients, 11 with moderate and 9 with severe COPD. Sputum induction was not done in 4 of the patients included in the original study; in 1 due to early withdrawal caused by COPD exacerbation and in further 3 due to $\mathrm{FEV}_{1}<35 \%$ of predicted on each visit. In 2 out of 20 patients included in the present study, sputum induction was not performed on Day 1 only $\left(\mathrm{FEV}_{1}\right.$ values $<35 \%$ of predicted), and in another 2 on Day 32 only (one was withdrawn on Day 18 due to acute respiratory tract infection and the other dropped out from the study).

As illustrated in Figure 1, the highest saline concentration was used in approximately half of the patients. The procedure was well tolerated and no subject reported adverse events. A total of 11 inductions (14\%) had to be prematurely discontinued due to an excessive bronchial constriction (fall of $\mathrm{FEV}_{1}>20 \%$ from the baseline value). This occurred in 6 patients, 2 with moderate and 4 with severe COPD. Three of these patients discontinued one induction only and well tolerated the procedure on the remaining 3 occasions; in two patients the induction was discontinued twice, while in the last one the induction had to be prematurely terminated each time. This patient had a pronounced airway obstruction ( $\mathrm{FEV}_{1} 38 \%$ of predicted) and reacted with an excessive bronchial constriction even after inhalation of normal saline. In further two patients the induction was terminated after the third inhalation interval due to large quantity of sputum collected up to that point.

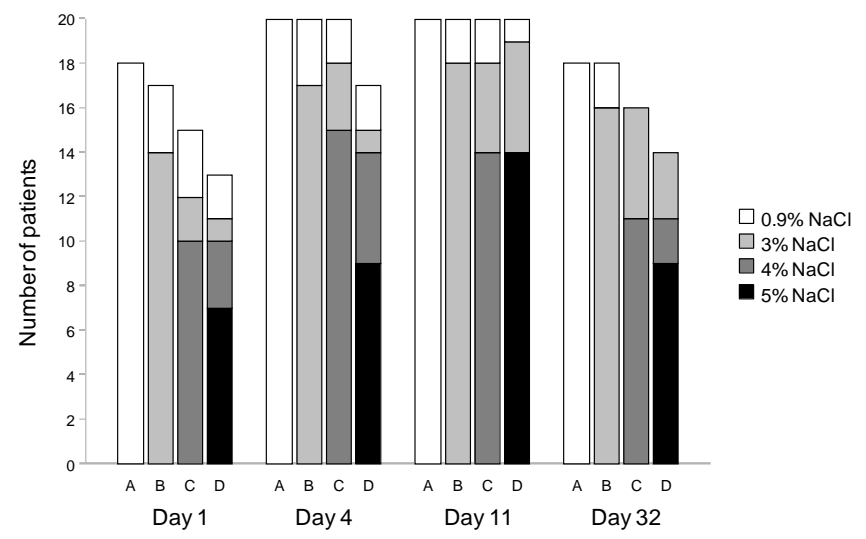

Figure 1. Frequency of various saline concentrations used for sputum induction in patients with moderate to severe COPD. A-D denotes the successive 7-minute inhalation intervals within each induction.

Observed changes in $\mathrm{FEV}_{1}$ during sputum induction are summarized in Table 1. Overall, the median fall of $\mathrm{FEV}_{1}$ at the end of sputum induction was $127 \mathrm{~mL}(95 \% \mathrm{CI} 90-176 \mathrm{~mL})$ or $10 \%$ (95\% CI 7-11\%) from baseline post-bronchodilator value. There was a significant difference in the change of $\mathrm{FEV}_{1}$ values between the different inhalation intervals on days 1, 4, 11 and 32 (Friedman's ANOVA, p < 0.0001). The decline in the $\mathrm{FEV}_{1}$ was greater as the concentration of inhaled saline was higher (Figure 2).

Table 1. Descriptive statistics of changes $(\%)$ in $\mathrm{FEV}_{1}$ during sputum induction in patients with moderate to severe COPD. A-D denotes the successive 7-minute inhalation intervals within each induction.

\begin{tabular}{|l|l|l|l|l|l|l|}
\hline Study day & $\begin{array}{l}\text { Inhalation } \\
\text { interval }\end{array}$ & $\mathrm{N}$ & Mean $\pm \mathrm{SD}^{*}$ & Median $(\mathrm{IQR})^{* *}$ & $\begin{array}{l}\text { Minimum } \\
\text { value }\end{array}$ & $\begin{array}{l}\text { Maximum } \\
\text { value }\end{array}$ \\
\hline \multirow{5}{*}{ Day 1 } & $\mathrm{A}$ & 18 & $-7.6 \pm 7.7$ & $-4.9(-10.1,-4.0)$ & -33.9 & 0.4 \\
\cline { 2 - 7 } & $\mathrm{B}$ & 17 & $-10.3 \pm 7.9$ & $-7.7(-16.1,-5.6)$ & -24.3 & 1.5 \\
\cline { 2 - 7 } & $\mathrm{C}$ & 15 & $-10.6 \pm 7.0$ & $-10.1(-16.8,-5.7)$ & -23.0 & 0.8 \\
\cline { 2 - 7 } & $\mathrm{D}$ & 13 & $-12.6 \pm 9.4$ & $-9.2(-18.8,-6.2)$ & -30.3 & -1.3 \\
\hline \multirow{5}{*}{ Day 4 } & $\mathrm{A}$ & 20 & $-4.8 \pm 5.3$ & $-3.9(-6.8,-1.9)$ & -18.0 & 3.0 \\
\cline { 2 - 7 } & $\mathrm{B}$ & 20 & $-6.7 \pm 8.4$ & $-7.5(-12.0,-3.5)$ & -17.7 & 14.6 \\
\cline { 2 - 7 } & $\mathrm{C}$ & 20 & $-13.0 \pm 10.2$ & $-10.0(-17.9,-4.8)$ & -39.8 & 0.0 \\
\cline { 2 - 7 } & $\mathrm{D}$ & 17 & $-13.5 \pm 8.3$ & $-11.3(-21.2,-7.5)$ & -25.9 & 0.5 \\
\hline \multirow{5}{*}{ Day 11 } & $\mathrm{A}$ & 20 & $-4.7 \pm 6.9$ & $-5.2(-8.4,-1.1)$ & -17.6 & 11.1 \\
\cline { 2 - 7 } & $\mathrm{B}$ & 20 & $-7.6 \pm 6.4$ & $-8.1(-10.9,-4.2)$ & -19.2 & 5.8 \\
\cline { 2 - 7 } & $\mathrm{C}$ & 20 & $-8.0 \pm 7.5$ & $-7.8(-13.0,-4.7)$ & -19.4 & 12.5 \\
\cline { 2 - 7 } & $\mathrm{D}$ & 20 & $-13.1 \pm 13.7$ & $-12.8(-19.6,-8.8)$ & -41.6 & 28.8 \\
\hline \multirow{5}{*}{ Day 32 } & $\mathrm{A}$ & 18 & $-5.4 \pm 5.5$ & $-4.8(-8.4,-2.0)$ & -19.5 & 5.9 \\
\cline { 2 - 7 } & $\mathrm{B}$ & 18 & $-10.2 \pm 10.0$ & $-8.6(-15.1,-3.6)$ & -36.0 & 2.5 \\
\cline { 2 - 7 } & $\mathrm{C}$ & 16 & $-9.8 \pm 7.4$ & $-9.1(-15.6,-5.2)$ & -22.8 & 5.9 \\
\cline { 2 - 7 } & $\mathrm{D}$ & 14 & $-14.2 \pm 6.0$ & $-15.3(-16.4,-8.7)$ & -24.0 & -4.8 \\
\hline
\end{tabular}

*SD - Standard deviation; **IQR - Interquarile range 
Day 1

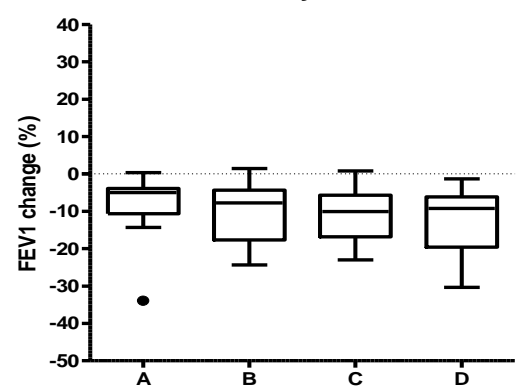

Day 11

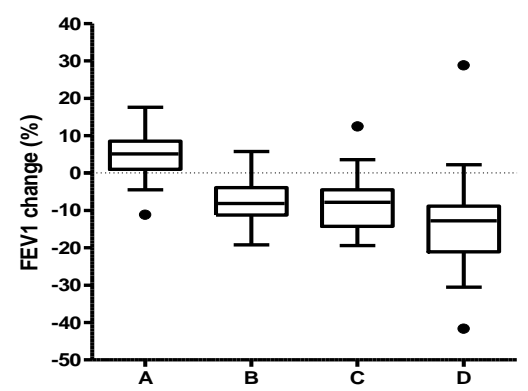

Day 4

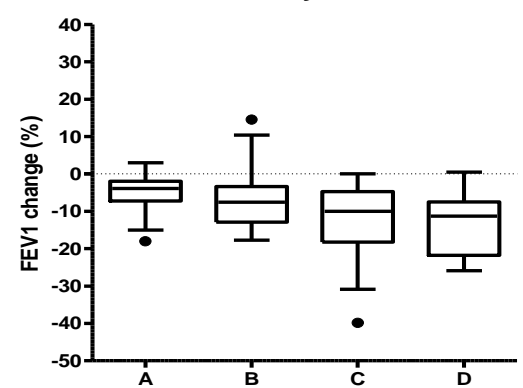

Day 32

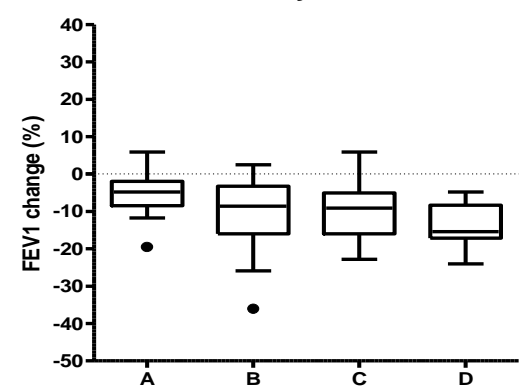

Figure 2. Fall in $\mathrm{FEV}_{1}$ values during each inhalation interval (A-D) within sputum induction on study days 1, 4, 11 and 32. Data are displayed as box-and-wisker plots (median, lower and upper quartile, non-outlier minimum and maximum), black points denote extremes.

A total of $55(72 \%)$ inductions were successful in terms of providing a sputum sample for analysis. At least one sample was collected from $17(85 \%)$ patients; $10(50 \%)$ patients produced sputum at each induction and further $5(25 \%)$ at 3 out of 4 occasions. Among 3 patients who failed to provide sputum at any induction, one prematurely discontinued all inductions due to an excessive broncho constriction, however, the remaining 2 inhaled up to $5 \%$ saline each time.

\section{Discussion}

The results of the study indicate that the described method of sputum induction is well tolerated by patients with moderate to severe COPD. The same patient underwent the sputum induction process at four occasions, which makes this study unique and most accurate from the point of safety assessment and lung function measurements. It should be noted that for safety reasons, patients with $\mathrm{FEV}_{1}<30 \%$ predicted were not included in the study, therefore, none of the patients was in the very severe or stage IV of the disease. Makris and al. have already shown that those patients are at an increased risk of unsuccessful sputum induction and adverse events (20). Our protocol wasn't modified for subjects with more severe disease as in some studies, instead, for safety reasons all patients started the procedure with normal saline for 7 minutes and then proceeded to higher concentrations. It turned out that such caution was reasonable, because one of the patients had an excessive bronchial spasm (fall in $\mathrm{FEV}_{1}$ of $33.9 \%$ from baseline) even after normal saline. The same patient had the maximal change in $\mathrm{FEV}_{1}(-41.6 \%)$ considering all of the inductions and the worse baseline lung function $\left(\mathrm{FEV}_{1} 38 \%\right.$ predicted), pointing out that extra care should be taken of the patients with a severe decline in lung function.

Inhalation of saline, both normal and hypertonic, caused a decline in $\mathrm{FEV}_{1}$. We've observed a slightly greater fall in $\mathrm{FEV}_{1}$ during the procedure than the other authors $(12,14,15,16,20,22)$. This difference in results is understandable as in all but one of these studies (14), the induction was terminated when the minimal sputum volume was reached, and not after the final saline concentration, as we did. This naturally resulted in longer inhalation times and higher concentrations inhaled. The proportion of inductions ending after the final, $5 \%$ saline, concentration was $50 \%$ in our study compared to $0 \%, 4 \%$ and $16 \%$ in other studies $(11,17,22)$. Despite the pre-treatment with $200 \mu \mathrm{g}$ salbutamol, some of the patients developed an excessive drop of lung function parameters. This is in agreement with all the previous observations of pre-treatment not giving a complete protection against bronchospasm $(7,11,15,16)$. Some authors have found that administration of nebulised salbutamol during the sputum induction could improve bronchoprotection in asthma patients (22). If patients have low lung function, premedication should be with $400 \mathrm{mcg}$ of salbutamol, and patients could also 
The Tolerability And Safety Of Repeated Sputum Induction In Patients With Moderate To Severe...

benefit from additional dose of salbutamol solution during inhalation of hypertonic saline. Following the appropriate standardized treatment after drop of $\mathrm{FEV}_{1}$, their lung function soon returned to the value within $10 \%$ of the baseline. This confirms once more the need for adequately trained and experienced personnel performing the inductions. Recently, it was found that sputum induction is a safe procedure even in COPD exacerbation (23), and in exercise-induced bronchoconstriction in asthma (24).

An interesting observation was that some of the patients felt less breathless after the sputum induction, despite the bronchoconstriction. There are some publications reporting that nebulised isotonic saline given in COPD, although not changing the lung function indicators such as $\mathrm{FEV}_{1}$, does indeed improve breathlessness, probably by a mechanism of enhanced mucus clearance and, therefore, easier expectoration $(18,25)$. Long ago it was found that hypertonic saline enhances clearance of lung secretions in COPD patients (26) perhaps by facilitating the collection of small amounts of pre-existing airway secretions (27). There are new data that hypertonic saline inhalation speeds up the resolution of exacerbation symptoms in cystic fibrosis exacerbations (28). As we haven't objectively assessed patients' dyspnoea during the study, it would be of interest to quantify it in future studies, possibly by using a visual analogue scale or Borg scale for dyspnoea. This was performed in the studies of Taube and al. (7) and Makris and al. (20), which showed the worsening of dyspnoea scores, even after normal saline inhalation. Possible reasons for conflicting results may include a difference in the study populations in terms of severity of the disease, as well as, different procedure protocols or nebulizer outputs. A study in asthmatics has shown that the general discomfort is proportional to the nebulizer output (29), and another study in COPD patients indicated that the high-output nebulizers, compared to the low-output ones, produced a significantly larger drop in $\mathrm{FEV}_{1}$ and a significantly shorter tolerated nebulization time (30). We have used a low-output nebulizer $(1 \mathrm{~mL} / \mathrm{min})$ compared to $1.7 \mathrm{~mL} / \mathrm{min}$ used by Taube et al. (7), while the output of the high-output nebulizer used by Makris et al. (20) was not specified.

In conclusion, we found that the method used for sputum induction was safe and well tolerated by patients with moderate and severe COPD. Patients with a more severe airway obstruction may have a higher risk of excessive broncho constriction and in this patient population extra caution should be taken even when using lower saline concentrations. Results of this study support the use of sputum induction in clinical and research practice.

\section{Acknowledgments}

We would like to thank GlaxoSmithKline Research Centre Zagreb Ltd. (successor of PLIVA Research Centre Ltd.) for granting access to raw data analysed in this study, and to acknowledge Dr. Suzana Sinovčić-Kolanović and Mrs. Andreja Škarica for valuable help in preparing data sets for statistical analysis.

\section{Author disclosure statement:}

Data presented in this paper have been collected during the clinical study on immunomodulatory effects of azithromycin in COPD, sponsored by Pliva Research Institute Ltd. Three of the authors have been involved in that study; Sanja Popović-Grle and Zoran Manojlović as clinical investigators, and Katarina Orešković, who was an employee of the sponsor, as the study manager and monitor.

During the last three years, Sanja Popović-Grle has also participated in the advisory board committee and/or performed as a keynote speaker and/or has attended further postgradual education sponsored by Boehriger Ingelheim, Novartis, AstraZeneca, Pliva - Teva, Takeda, GlaxoSmithKline, Meda Pharma, SanofiAventis, Krka-farma, Berlin-Chemie Menarini Hrvatska, or Sandoz Hrvatska, respectively. Paško Konjevoda, who performed statistical analysis of data for the present study, and Latica Friedrich, who prepared the first draft of the manuscript, declare no conflict of interest. All of the authors have contributed to the final version of the manuscript.

\section{References}

[1]. Miravittles M, Barrecheguren M, Roman-Rodriguez M. Frequency and characteristics of different clinical phenotypes of chronic obstructive pulmonary disease. Int J Tuberc Lung Dis 2015;19(8):992-8.

[2]. Koblizek V, Chlumsky J, Zindr V et al. Chronic obstructive pulmonary disease: official diagnosis and treatment guidelines of the Czech pneumological and phthisiological society; a novel phenotypic approach to COPD with patient-oriented care. Biomed Pap Med Fac Univer Palacky Olomouc Czeck Repub 2013;157(2): 189-201.

[3]. Wenzel S. Complex phenotypes in asthma: current definitions.

[4]. Pulm Phalmacol Ther 2013; 26(6):710-5.

[5]. Global strategy for asthma management and prevention. 2015. (Accessed January 2016, at www.ginasthma.org )

[6]. Pin I, Freitag AP, O’Byrne PM, Girgis-Gabardo A, Watson RM, Dolovich J, Denburg JA, Hargreave FE. Changes in the cellular profile of induced sputum after allergen-induced asthmatic responses. Am Rev Respir Dis 1992;145(6):1265-0.

[7]. Pizzichini E, Pizzichini MM, Ethimidias A, Evans S, Morris MM, Squillace D, Gleich GJ, Dolovich J, Hargreave FE. Indices of airway inflammation in induced sputum: reproducibility and validity of cell and fluid-phase measurements. Am Rev Respir Dis 1996;154(2 Pt 1):308-17.

[8]. Taube C, Holz O, Mücke M, Jörres RA, Magnussen H. Airway response to inhaled hypertonic saline in patients with moderate to severe chronic obstructive pulmonary disease. Am J Respir Crit Care Med 2001;164(10):1810-1815. 
The Tolerability And Safety Of Repeated Sputum Induction In Patients With Moderate To Severe...

[9]. Wong HH, Fahy JV. Safety of one method of sputum induction in asthmatic subjects. Am J Respir Crit Care Med 1997;156(1):299303.

[10]. de la Fuente PT, Romagnoli M, Godard P, Bousquet J, Chanez P. Safety of inducing sputum in patients with asthma of varying severity. Am J Respir Crit Care Med 1997;157(4):1127-1130.

[11]. Grootendorst DC, van den Bos JW, Romeijn JJ, Veselic-Charvat M, Duiverman EJ, Vrijlandt EJ, Sterk PJ, Roldaan AC. Induced sputum in adolescents with severe stable asthma. Safety and the relationship of cell counts and eosinophilic cationic protein to clinical severity. Eur Respir J 1999;13(3):647-653.

[12]. Vlachos-Mayer H, Leigh R, Sharon RF, Hussack P, Hargreave FE. Success and safety of sputum induction in the clinical setting. Eur Respir J 2000;16(5):997-1000.

[13]. Paggiaro PL, Chanez P, Holz O. Sputum induction. Eur Respir J 2000;(Suppl. 37):3s-8s.

[14]. Popov TA, Pizzichini MM, Pizzichini E, Kolendowicz R, Punthakee Z, Dolovich J, Hargreave. Some technical factors influencing the induction of sputum for cell analysis. Eur Respir J 1995;8(4):559-65.

[15]. Kelly MG, Brown V, Martin SL, Ennis M, Elborn JS. Comparison of sputum induction using high-output and low-output ultrasonic nebulizers in normal subjects and patients with COPD. Chest 2002;122(3):955-959.

[16]. Sutherland ER, Pak J, Langmack EL, Silkoff PE, Martin RJ. Safety of sputum induction in moderate-to-severe chronic obstructive pulmonary disease. Respir Med 2002; 96(7):482-486.

[17]. Pizzichini E, Pizzichini MMM, Leigh R, Djukanović R, Sterk PJ.Safety of sputum induction. Eur Respir J 2002;(Suppl. 37):9s-18s.

[18]. Wilson AM, Leigh R, Hargreave FE, Pizzichini MM, Pizzichini E. Safety of sputum induction in moderate-to-severe smokingrelated chronic obstructive pulmonary disease. COPD 2006;3(2):89-93.

[19]. Parnham MJ, Čulić O, Eraković V, Munić V, Popović-Grle S, Barišić K, Bosnar M, Brajša K, Čepelak I,Čužić S, Glojnarić I, Manojlović Z, Novak-Mirčetić R, Orešković K, Pavičić-Beljak V, Radošević S, Sučić M. Modulation of neutrophil and inflammation markers in chronic obstructive pulmonary disease by short-term azithromycin treatment. Eur $\mathrm{J}$ Pharmacol 2005;517(1-2):132-143.

[20]. Global Initiative for Chronic Obstructive Lung Disease (GOLD). Global Strategy for Diagnosis, Management and Prevention of COPD. Available from www.goldcopd.org, accessed January 2016.

[21]. Makris D, Tzanakis N, Moschandreas J, Siafakas NM. Dyspnea assessment and adverse events during sputum induction in COPD. BMC Pulm Med 2006;6:17.

[22]. Rytilä PH, Lindqvist AE, Laitinen LA. Safety of sputum induction in chronic obstructive pulmonary disease. Eur Respir $\mathbf{J}$ 2000;15(6):1116-1169.

[23]. Delvaux M, Henket M, Lau L, Kange P, Bartsch P, Djukanovic R, Louis R. Nebulised salbutamol administered during sputum induction improves bronchoprotection in patients with asthma. Thorax 2004;59:111-5.

[24]. Gao P, Gibson PG, Zhang J, He X, Hao Y, Li P, Liu H. The safety of sputum induction in adults with acute exacerbation of COPD Clin Respir J 2013;781):101-9.

[25]. Carlsten C, Aitken ML, Hallstrand TS. Safety of sputum induction with hypertonic saline in exercise-induced bronchoconctriction, Chest 2007;131(5):1339-44.

[26]. Brightling CE, Monterio W, Green RH, Parker D, Morgan MD, Wardlaw AJ, Pavord D. Induced sputum and other outcome measures in chronic obstructive pulmonary disease: safety and repeatability. Respir Med 2001;95(12):999-1002.

[27]. Beeh KM, Beier J, Kornmann O, Mander A, Buhl R. Long-term repeatability of induced sputum cells and inflammatory markers in stable, moderately severe COPD. Chest 2003;123(3):778-783.

[28]. Khan SY, O'Driscoll BR. Is nebulized saline a placebo in COPD? BMC Pulm Med 2004;4:9.

[29]. Dentice RL, Elkins MR, Middleton PG, Bishop JR, Wark PA, Dorahy DJ, Hamer CJ, Hu H, Bye PT. A randomised trial of hypertonic saline during hospitalization for exacerbation of cystic fibrosis. Thorax 2016;71(2):141-7.

[30]. Poole PJ, Brodie SNM, Stewart JM, Black PN. The effects of nebulised saline and terbutalin on breathlessness in severe chronic obstructive pulmonary disease (COPD). Aust N Z J Med 1998;28(3):322-6.

[31]. Pavia D, Thomson ML, Clarke SW. Enhanced clearance of secretions from the human lung after the administration of hypertonic saline aerosol. Am Rev Respir Dis 1978;117(2):199-203. 